\title{
PENDIDIKAN MULTIKULTURAL MELALUI PROGRAM BAHASA HOLISTIK (PENELITIAN PENGEMBANGAN DI KELOMPOK B TAMAN KANAK-KANAK NASIMA SEMARANG)
}

\author{
ROOSTRIANAWAHTI SOEKMONO \\ Universitas Trilogi \\ Roostri73@trilogi.ac.id
}

\begin{abstract}
A challenging diversity in Indonesian society turns out to be cultural asset and conflict. Tolerance is the main key to ease up the cultural conflict through multicultural education. Early childhood can be taught about diversity awareness by diversity experience, which is a basic step development of tolerance. This study is aimed to uncover learning strategy in enhancing diversity awareness, such as, understanding diversity, skill in communicating diversity and treating diversity positively. This study employs Research and Development approach modified into three phases of research: preliminary study, development model and validation test model. In the preliminary study, bibliographical study discusses multicultural theme "What a Beautiful Diversity in the Old Town" and social background study about children culture in Semarang city. Development model consist of five steps based on five concepts, namely, identification of multicultural theme, unit planning of multicultural theme with whole language programme, preparation for game apparatus and books about multicultural stories, implementation of multicultural learning, and assesment on diversity awareness. Validation test model is comprised of assesment validation about diversity awareness and models of validation by experts. It's significant, effective and appropriate. Discoveries resulting from study, communication and participation are factors influencing level of diversity awareness.
\end{abstract}

Keywords: Model Development, Multicultural Education, Whole Language Programme and Diversity awareness

\begin{abstract}
Abstrak: Masyarakat Indonesia yang beragam merupakan tantangan, menjadi modal budaya atau konflik budaya. Konflik budaya dapat dikurangi dengan mengembangkan sikap toleran melalui pendidikan multikultural. Pada anak usia dini kita dapat meningkatkan kesadaran tentang keberagaman, yang merupakan dasar dari sikap toleran. Penelitian ini diperlukan untuk menemukan strategi pembelajaran untuk meningkatkan kesadaran tentang keberagaman, seperti memahami, mengkomunikasikan dan menyikapi keberagaman dengan cara positif. Pendekatan penelitian menggunakan Penelitian dan Pengembangan yang dimodifikasi dalam tiga langkah penelitian yaitu: studi pendahuluan, model pengembangan dan model tes validasi. Studi pendahuluan berisi studi pustaka untuk tema multikultural "Indahnya keberagaman kota lama" dan studi latar belakang sosial budaya anak. Model pengembangan mempunyai lima langkah yang dikembangkan dari lima konsep yaitu identifikasi tema multikultural, perencanaan unit dari tema multikultural dengan program bahasa holistik, Persiapan alat permainan dan buku cerita multikultural, implementasi pembelajaran multikultural, dan asesmen kesadaran tentang keberagaman. Model tes validasi berupa validasi asesmen kesadaran tentang keberagaman dan validasi model oleh pakar. Asesmen kesadaran tentang keberagaman dalam uji coba kelompok kecil adalah signifikan, model terbukti efektif meningkatkan kesadaran tentang keberagaman. Pakar menyatakan model layak. Temuan penelitian komunikasi dan partisipasi adalah faktor yang berpengaruh untuk meningkatkan kesadaran tentang keberagaman. Komunikasi dan partisipasi pada usia dini dipengaruhi oleh budaya suku dan suku mayoritas
\end{abstract}

Kata Kunci: Pengembangan Model, Pendidikan Multikultural, Program Whole Language dan Keanekaragaman 


\section{PENDAHULUAN}

Indonesia merupakan negara kepulauan terbesar dengan 247 suku bangsa yang tersebar di seluruh wilayah. (Portal Nasional RI, 2014) Keberagaman tergambar nyata, keberagaman merupakan modal budaya yang luar biasa, tetapi apabila disikapi dengan cara negatif menimbulkan masalah disintegrasi bangsa, konflik antar etnis dan kekerasan. Hal ini terjadi karena belum semua dapat menerima, menghargai dan toleransi pada keberagaman meskipun Indonesia merupakan bangsa multikultural. Konflik, kekerasan. dan budaya global dikonsumsi anak melalui media cetak elektronik, akibatnya anak meniru. Kondisi ini diperkuat dengan film-film kartun asing, buku cerita, komik, tempat bekal, mainan anak, kartu-kartu, baju, tas dan benda-benda lain yang dipakai anak, sehingga mereka lebih mengenal tokoh-tokoh luar, identitas budaya lokal dan nasional mereka terancam. Ironinya pendidikan multikultural masih menjadi wacana di sekolah (https://www.kompasiana.com/rhesa ardy, 2017)
Penelitian dan pengembangan ini mengimplementasikan pendidikan multikultural melalui pengenalan budaya lokal-Nasional-global di kota Semarang melalui tema multikutural "Indahnya Keberagaman Kota Lama". Kota Lama adalah kawasan di kota Semarang yang di dalamnya terdapat empat kampung etnis yaitu kampung Kauman, Belanda, Pecinan dan Melayu yang merupakan budaya Lokal. Kampung etnis juga terdapat di kota dan kabupaten lain di Indonesia, sehingga keberagaman suku di kampung etnis merupakan budaya Nasional dan di negaranegara lain juga ada ethnics enclave yang merupakan budaya global, yaitu suatu kampung tempat berkumpulnya satu atau beberapa etnis/suku tertentu. Kota Lama dihuni beragaman suku yaitu suku Jawa, Melayu, Banjar, Arab, Cina dan Indo-Belanda (Titik Suliyati, 2014:3). Anak didik juga diajak memahami, mengkomunikasikan dan menyikapi keberagaman sukubudaya di Kota Lama dengan cara positif, karena anak belajar norma dari budaya mereka, pada waktu yang sama dan dengan cara yang 
sama mereka belajar untuk berbicara suatu bahasa (Dodge, Laura, Heroman., 2002: 35). Anak-anak diajak memprak-tekkan hal tersebut di atas karena dalam kesehariannya mereka melihat dan meniru hal-hal negatif, kekerasan, stereotipe dan diskrimina-si ketika menyikapi keberagaman. Mereka mengekspresikan hal-hal tersebut dalam ucapan dan perilaku. Contohnya ketika anak melihat temannya yang berkulit gelap anak spontan bertanya, "Kamu kok hitam sih?", temannya langsung berteriak, “aku tidak hitam !", akhirnya terjadi pertengkaran karena ucapan tersebut tanpa disadari anak mengandung diskriminasi fisik yang menyebabkan temannya marah.

Pengembangan pendidikan multikultural melalui program bahasa Holistik penting dilakukan karena: (1) bahasa Indonesia sudah terbukti menjadi bahasa pemersatu pada peristiwa Sumpah Pemuda tahun 1928; (2) Anak belajar norma dari budaya mereka pada waktu yang sama dan dengan cara yang sama mereka belajar untuk berbicara suatu bahasa (Dodge, Laura, Heroman.,
2002: 35); dan (3) Bahasa holistik berfokus pada maksud dan pengalaman, menyebar ke semua bagian kurikulum (Weaver, 1990: 6). Oleh karena itu peneliti tertarik mengembangkan "Model Pendidikan Multikultural melalui Program Bahasa Holistik”.

\section{KAJIAN TEORITIK}

Konsep Desain Pengembangan Model

Beberapa konsep inti dari model yang dikembangkan yaitu:

\section{Konsep pengembangan tema multicultural}

Konsep tema multikultural dikembangkan dari sistem tricentra $\mathrm{Ki}$ Hajar Dewantara yang muaranya adalah watak kulturil bangsa/adab kebangsaan (Ki Hajar Dewantara, 1977). Selaras dengan ide Tilaar tentang penanaman nilai-nilai budaya lokal - keindonesiaan - global dalam kurikulum yang bermuara pada civic intellegence, sehingga apabila disintesis dapat dijadikan bingkai atau framework tema multikultural yang dapat digambarkan dalam bagan berikut ini (HAR Tilaar, 2002). 


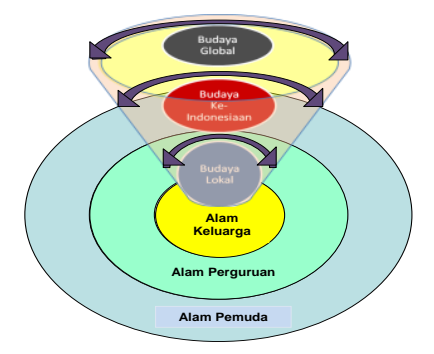

Gambar 1. Framework tema multikultural

\section{Konsep pengembangan asesmen perkembangan kesadaran tentang keberagaman}

Menurut Connell dkk. konsep tentang keberagaman memang harus dikembangkan dalam pembelajaran melalui eksplorasi dan komunikasi positif tentang praktek sosial dan budaya orang-orang yang ada di lingkungannya (Connell,2006 h.72), yang dapat digambarkan seperti bagan di atas:

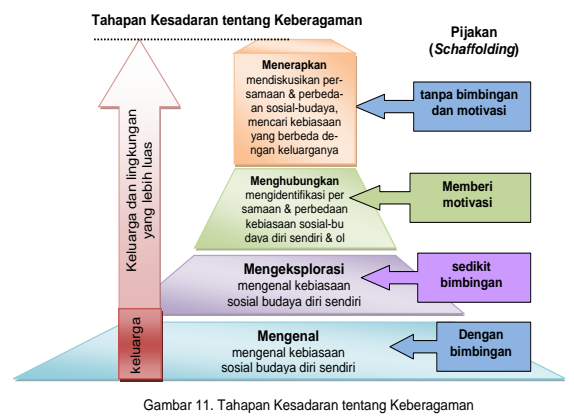

Gambar 2. Tahapan Kesadaran tentang Keberagaman

\section{Konsep pengembangan perenca- naan pembelajaran model webbed.}

Dari pendapat beberapa ahli dalam merencanakan pembe-lajaran menggunakan model webbed dapat disimpulkan bahwa guru melewati beberapa langkah:

Mengidentifikasi konsep-konsep minat anak; (2) Guru melakukan brain-storming untuk membuat jaringan tema/topik yang berisi rencana unit, ren-cana aktivitas; (3) Menjamin setiap webbed berisi pengalaman anak yang dapat dihubungkan dengan tujuan yang ingin dicapai; (4) Mempersiapkan lingkungan belajar. (5) Melakukan assesmen dan evaluasi.

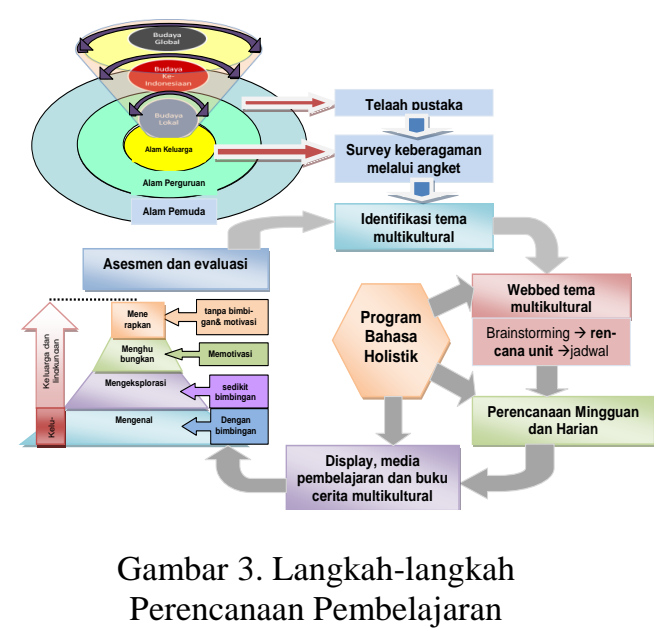

Konsep pengembangan pelaksa-naan pembelajaran model webbed, Pendidikan multikultural dapat 
diinte-grasikan dalam dua domain

yaitu: (1) Penataan Domain

Lingkungan Kelas Multikultural

lingkung-an yang kaya untuk eksplorasi gender, ras/etnis, dan perbeda-an lain (Spark, 2001: h.11),

(2) Domain Strategi Pembelajaran

Multikultural, yaitu: menyikapi

Perbedaan dan Persamaan Ras/Fisik, gender, dan perbedaan lain (Spark, 2001: h. 66-69).

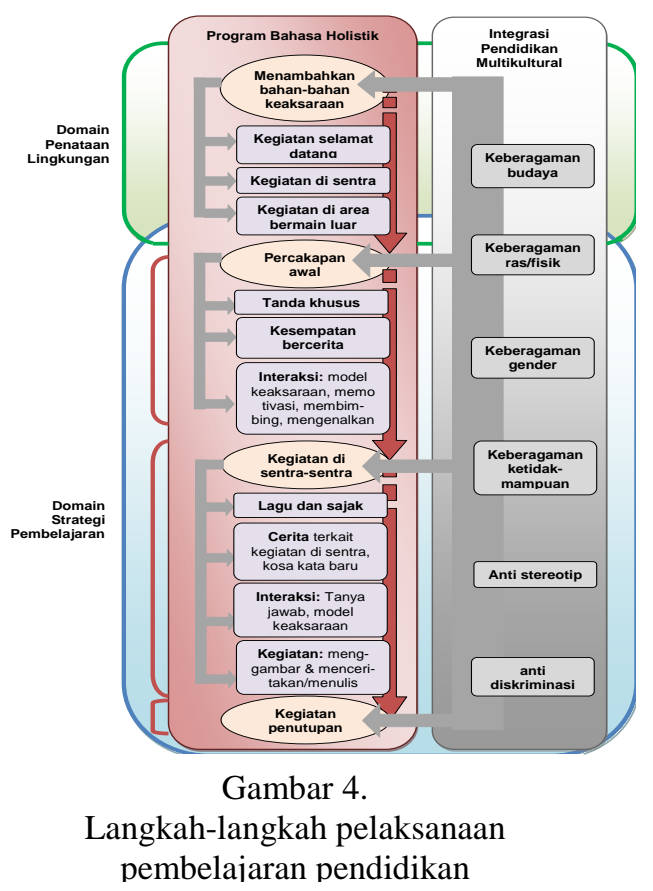

(3) Konsep pengembangan program bahasa holistik melalui kegiatan bercerita (format utuh bahasa holistik) menggunakan media buku cerita multikultural dan boneka multikultural. Buku cerita multikultural diperlukan anak untuk mengeksplorasi dan memahami berbagai budaya lain, membantu sensitivitas dan apresiasi pada orang dari kelompok lain, serta membantu anak berinteraksi dengan orang lain lebih baik.

\section{Konsep Model yang Dikembang-} kan

\section{Konsep Pendidikan Multikultural}

Menurut Tilaar, pendidikan multikultural menfokuskan pada kelompok-kelompok agama, ras, masalah kemiskinan, penindasan dan keterbelakangan kelompok minoritas dalam ilmu pengetahuan. Konsep pendidikan multikultural mengembangkan nilai-nilai demokratis dan telah merambah sebagai bagian dari perubahan sosial (Tilaar, 2002: h. 498)

Secara lebih operasional, Banks menjabarkan dalam empat dasar pendekatan pendidikan multikultural, yaitu: (1) The Contributions Approach, yang terfokus pada rasa heroik, hari besar budaya terkait dengan makanan, hadiah dan pakaian; (2) The Additional Approach, menambahkan konsep budaya (kematian, kelahiran, 
partisipasi sosial), tema (ekologi, keadilan); (3) The Transformation Approach, mengalirkan perubahan struktur dan di-daktik yang berguna bagi anak dalam memandang konsep, isu-isu, kejadian dan tema berbagai perspektif perbedaan etnik dan budaya kelompok;

(4) The

Social Action Approach, menyediakan perubahan lebih lanjut dalam metodologi pendidikan, anak berperan dalam membuat keputusan terhadap beragam isu sosial dan membantu memecahkan beragam masalah (Banks and Banks, 2004: h. 341).

\section{Program Bahasa Holistik di Taman Kanak-kanak}

Watson dalam Berk berpendapat bahwa pendekatan bahasa holistik harus diajar dengan bahasa alami melalui cara belajar paralel, pada anak yang masih muda atau anak usia dini harus ditunjukkan teks dalam format lengkap - berupa cerita, puisi, surat, poster dan daftar sehingga mereka dapat menghargai komunikasi bahasa dengan tulisan. Menurut para pakar, bacaan dijaga maknanya, agar anak termotivasi menemukan keterampilan spesifik yang mereka perlukan (Berk, 2006: h. 302).

Raines dan Canady dalam bukunya The Whole Language Kindergarten memaparkan 6 (enam) elemen kunci yang dapat digunakan guru dalam praktek pembelajarannya di Taman Kanak-kanak , yaitu:

(a) menenggelamkan anak dalam bahasa dan tulisan (immersion), (b) memberikan Kesempatan dan menyediakan berbagai sumber belajar, (c) melakukan Komunikasi yang Bermakna, (d) menjadi Model Komunikasi, (e) mendukung Anak menjadi Pembaca dan Penulis, (f) memotivasi anak dalam proses keaksaraan tanpa mempedulikan latar belakang pengalaman atau sosial, budaya dan bahasa anak (Raines, 1990: h. 10 - 13).

\section{Konsep Kesadaran tentang Keberagaman}

Keberagaman mulai disadari oleh anak ketika mereka mulai melihat, memperhatikan dan menyadari tentang adanya perbedaan atau keberagaman seperti jenis kelamin (gender), usia dan warna 
kulit. Menurut Milestone Kesadaran tentang keberagaman gender, usia dan warna kulit terjadi pada usia 3 tahun (Gronlund, 2001: h. 38)

Alejandro-Wright menemukan bahwa kesadaran tentang ras dimulai pada usia pra-sekolah, dan pemahaman anak akan lengkap pada usia 10 s.d. 11 tahun. Pada usia tersebut mereka bisa mengklasifikasikan ras tanpa melihat warna kulit yang berbeda tetapi berdasarkan pengetahuan tentang pengelompok kan tanda fisik biologis dari ras tertentu (Alejandro-Wright, 1985: h.186).

Penelitian tentang "Pendidikan Multikultural pada Anak Usia Dini (AUD)" oleh Hariyanto, Hasilnya pendidikan multikultural pada AUD diselenggarakan dengan pendekatan orientasi kurikulum, sistem pembelajaran berbasis sentrasentra, dan penanaman nilai-nilai perilaku positif karena materinya belum ada di kurikulum AUD. (Hariyanto,2013). Pada usia Prasekolah (2 s.d. 6 th) anak sedang dalam masa peka berkembangnya kesadaran tentang ras/ suku, berkembang menjadi toleransi pada usia 10-11 tahun (Alejandro-Wright, 1985:186).

$$
\text { Penelitian Pusat Kajian }
$$

Pembangunan Masyarakat (PKPM) Unika Atmajaya mengembangkan program ini sudah diujicoba di $8 \mathrm{SD}$ (Negeri dan swasta berbasis agama) di wilayah Jakarta, Depok, Tanggerang dan Bekasi. Hasilnya berupa peningkatan pemahaman dan afeksi anak tentang nilai-nilai multikultural, misal anak dapat menghargai (toleransi) perbedaan, solider, tidak berprasangka, dan tidak diskriminasi (Murniati, 2012). Menurut Connell dkk., konsep awal tentang keberagaman memang harus dikembangkan dalam proses pembelajaran melalui eksplorasi dan komunikasi positif tentang praktek sosial dan budaya orang-orang yang ada di lingkungannya (Connell, 2006:72).

Penelitian pendidikan multikultural di negara lain sudah banyak berkembang, contohnya "Promoting Young Children's Cultural Awareness and Appreciation Through Multicultural Books". Hasil penelitian ini adalah 
buku cerita tentang budaya dapat membantu AUD mengembangkan rasa hormat pada orang lain dan memperkuat pengalamannya dari latar belakang yang beragam.

Watson dalam Berk pendekatan bahasa holistik untuk AUD harus ditunjukkan teks dalam format lengkap, berupa cerita, puisi, surat, poster dan daftar, sehingga mereka dapat menghargai komunikasi bahasa dengan tulisan (Berk, 2006, 302). Piper mengungkapkan bahwa buku cerita multikultural dapat mengembangkan kesadaran tentang latar belakang bahasa dan budaya yang berbeda (Piper,1993:4).

Penelitian tentang kesadaran identitas suku "An Exercise in Ethnic Identity Awareness". Kesadaran Identitas suku meliputi konsep diri (self-concept) dan identitas diri (selfidentification), rasa memiliki (a sense of belonging), dan sikap-sikap positif dan negatif (positive and negative attitudes) terhadap suatu kelompok etnik. Peneliti mendeskripsikan latihan melalui pengenalan dan fasilitasi kesadaran dari konsep identitas suku melalui ilustrasi, pengalaman dan contoh kehidupan nyata, multidimensi identitas etnis (McNeill dan Brian W., 2001: 284). Penelitian ini sesuai model asesmen kesadaran tentang keberagaman, salah satu indikatornya adalah pemahaman tentang identitas suku dan harga diri yang kuat.

Penelitian ini secara umum bertujuan mengembangkan suatu model Pendidikan Multikultural melalui program bahasa holistik untuk meningkatkan kesadaran tentang keberagaman. Tujuan khusus penelitian adalah:

Mengidentifikasikan model atau pendekatan pembelajaran yang digunakan oleh guru TK untuk mendidik kesadaran tentang keberagaman anak TK; (2) mengidentifikasikan tingkat kesadaran tentang keberagaman anak TK; (3) Menemukan cara merancang model pendidikan multikutural melalui Program Bahasa Holistik yang dapat dikembangkan untuk anak TK; Mengidentifikasikan cara pelaksanaan model pendidikan multikultural melalui program 
Pendidikan Multikultural Melalui..... Roostrianawahti Soekmono

bahasa holistik di TK; (5) memperoleh data empiris peningkatan kesadaran tentang keberagaman anak TK setelah dilaksanakan pengembangan model Pendidikan Multikultural melalui Program Bahasa Holistik

\section{METODE PENELITIAN}

Metode Penelitian yang digunakan adalah Penelitian dan Pengembangan ( $R$ and $D)$ dengan desain pengembangan model Borg and Gall yang mengadaptasi the Systematic Design of Instructional dari Dick and Carey.
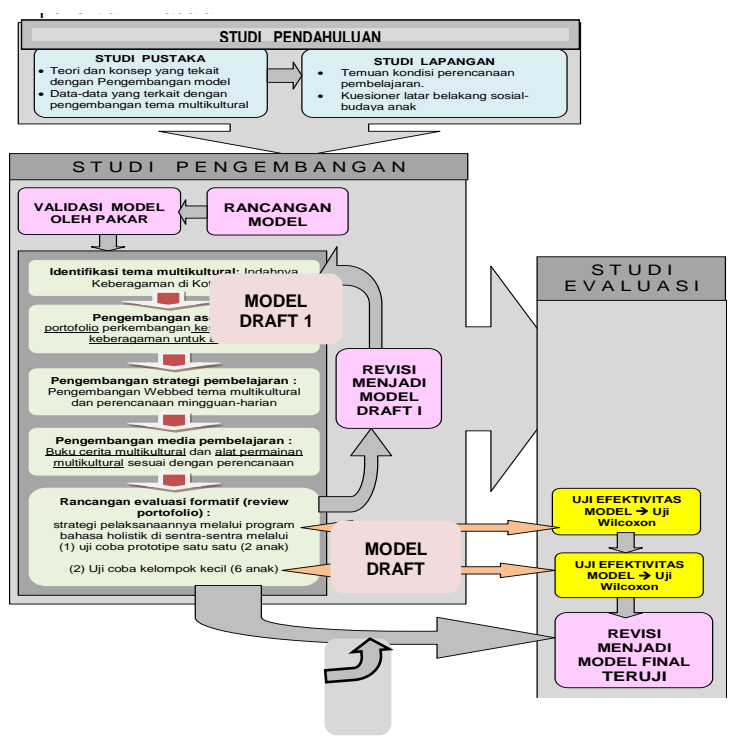

Gambar 5. Langkah-langkah Penelitian dan Pengembangan Model

\section{Rancangan Model (Model Draft 1)}

Rancangan model "Pendidikan Multikultural melalui Program Bahasa Holistik" berupa model konseptual, model prosedural dan model fisikal

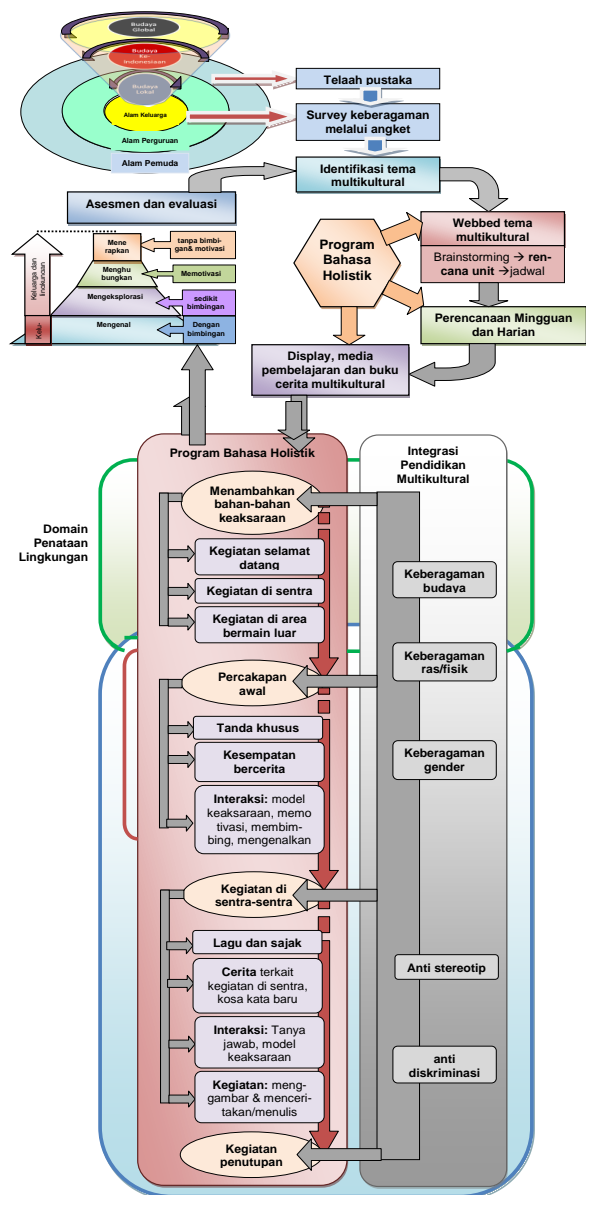

Gambar 7.

Rancangan Model Prosedural Pendidikan Multikultural 


\section{HASIL DAN PEMBAHASAN}

\section{Hasil Studi Pustaka}

Penelitian dan pengembangan

model pendidikan multikutural melalui program bahasa holistik dilaksanakan melalui perencanaan dan pelaksanaan pembelajaran model webbed dengan tema multikutural "Indahnya Keberagaman Kota Lama”. Peneliti menggunakan pertanyaan $5 \mathrm{~W} 1 \mathrm{H}$ agar pertanyaan logis: (1) Kampung apa yang ada di Kota Lama?, (2) Suku apa yang tinggal dan budaya apa yang berkembang di Kota Lama?, (3) Dimana letak kawasan Kota Lama?, (4) Kapan dan bagaimana Kawasan Kota Lama berdiri?, (5) Mengapa keberagaman suku dan budaya di Kota Lama begitu indah?

Data-data tersebut digunakan untuk identifikasi tema multikultural, yaitu: (a) ada empat kampung di Kota Lama: kampung Kauman, Belanda, Pecinan dan Melayu, (b) ada enam suku dan budaya: sukubudaya Jawa, Indo Belanda, Cina, Arab Handramaut, Banjar, dan Melayu (c) Kota Lama berdiri bertahap, awalnya kampung Kauman, lalu kampung Belanda,
Pecinan dan Melayu, (d) letaknya di sekitar jembatan Mberok: kampung Kauman di Barat, kampung Belanda di Timur, kampung Pecinan di Selatan, dan kampung Melayu di Utara, (e) keberagaman Kota Lama begitu indah karena masyarakatnya rukun (kearifan lokal intangible) dan keberagaman bangunan / budaya (kearifan lokal tangible). Di Indonesia kampung Kauman, Belanda, Pecinan dan Melayu ada di $\mathrm{Kab} /$ Kota lain di Indonesia (Budaya ke-Indonesiaan) dan negara-negara lain (Budaya Global).

\section{Hasil Studi Lapangan}

Hasil studi lapangan pada perencanaan pembelajaran TK Nasima Semarang diperoleh data rata-rata kegiatan yang mengangkat budaya lokal, nasional dan budaya global adalah sebagai berikut: 
Tabel 1. Prosentase Budaya LokalNasional-Global (L-N-G) dalam

Perencanaan Pembelajaran

Kelompok B TK Nasima Semarang

\begin{tabular}{|c|c|c|c|c|c|c|}
\hline No & Sentra & $\begin{array}{c}\text { Jumlah } \\
\text { Kegiatan }\end{array}$ & $\% \mathrm{~L}$ & $\% \mathrm{~N}$ & $\% \mathrm{G}$ & $\begin{array}{l}\% \mathrm{~L}- \\
\text { N-G }\end{array}$ \\
\hline 1 & $\begin{array}{c}\text { Persiapan } \\
\text { ABC }\end{array}$ & 5 & 100 & 0 & 0 & 33,3 \\
\hline 2 & $\begin{array}{c}\text { Persiapan } \\
123\end{array}$ & 6 & 16,5 & 0 & 0 & 5,5 \\
\hline 3 & Seni 1 & 8 & 50 & 0 & 0 & 16,5 \\
\hline 4 & Seni 2 & 5 & 40 & 0 & 0 & 13,3 \\
\hline 5 & $\begin{array}{c}\text { Bahan } \\
\text { Alam } 1\end{array}$ & 4 & 0 & 0 & 25 & 8,3 \\
\hline 6 & $\begin{array}{c}\text { Bahan } \\
\text { Alam } 2\end{array}$ & 2 & 0 & 0 & 100 & 33,3 \\
\hline 7 & $\begin{array}{c}\text { Bermain } \\
\text { peran }\end{array}$ & 4 & 0 & 0 & 0 & 0 \\
\hline 8 & Balok & 1 & 100 & 0 & 0 & 33,3 \\
\hline 9 & Permainan & 7 & 15 & 15 & 15 & 15 \\
\hline 10 & Nasima & 6 & 34 & 34 & 0 & 23 \\
\hline & & Rata-rata & & & & 18,15 \\
\hline
\end{tabular}

Rata-rata prosentase kegiatan yang mengangkat budaya lokalnasional-global di TK Nasima Semarang 18,15\%. Prosentase di bawah rata-rata $18,5 \%$ adalah sentra bermain peran $(0 \%)$, Sentra persiapan $123(5,5 \%)$ dan sentra seni 1-2 (15 \%). Peneliti melakukan penelitian di sentra persiapan 123 dan seni karena keterbatasan penelitian.

Data tentang suku anak-anak TK Nasima Semarang yang diperoleh dari 95 kuesioner yang terkumpul adalah sebagai berikut:

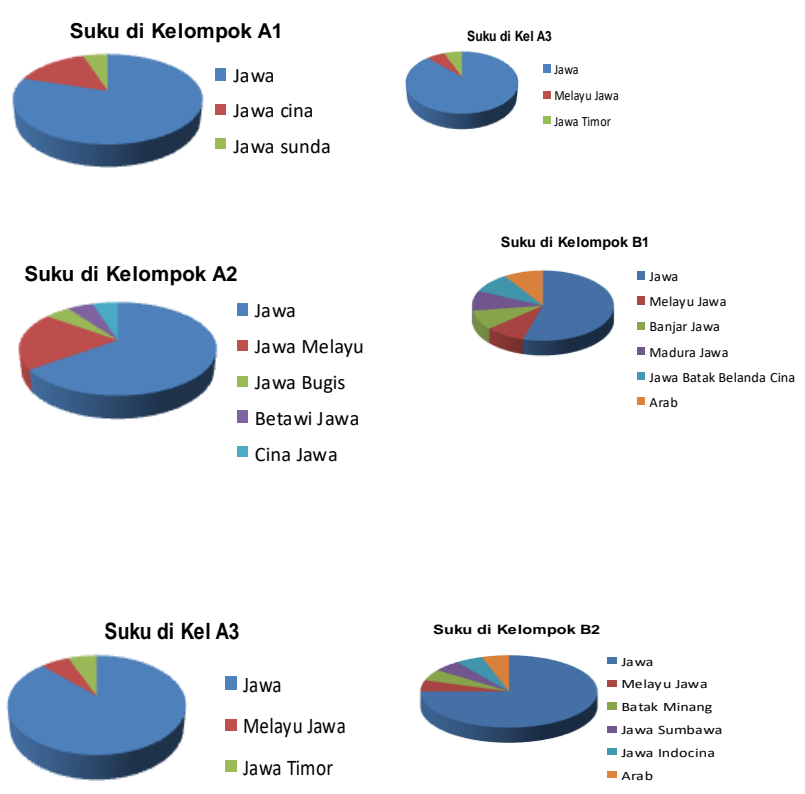

Gambar 8. Grafik Pie Keberagaman Suku di TK Nasima Semarang

an suku anak-anak TK Nasima Semarang ditemukan bahwa anak TK Kelompok B1 merupakan kelompok paling beragam sukunya, berikutnya adalah TK kelompok B2, A2, A1 dan A3. Sehingga sampel uji Prototipe dipilih 2 (dua) anak dari kelompok B2 yaitu: Ikhlas (Jawa) dan Keisha (Batak-Minang). Sampel uji kelompok kecil dipilih 6 anak dari Kelompok B2 yang sukunya hampir sama dengan suku-suku Kota Lama, yaitu: Khanza (Jawa), Raka (Jawa), Cheryl (Jawa-Batak Belanda Cina), Evan (Banjar-Jawa), Nasywah 
(Melayu-Jawa) dan Syaima (Arab Handramaut).

\section{Model Draft 2 dan Model Final}

Model draft 1 selanjutnya direvisi menjadi model draft 2, direvisi lagi menjadi model final. Berikut ini adalah revisi model fisikal rancangan model menjadi model draft I dan model final berupa empat modul workshop, buku cerita multikultu-ral, alat permainan multikutural, dan video.

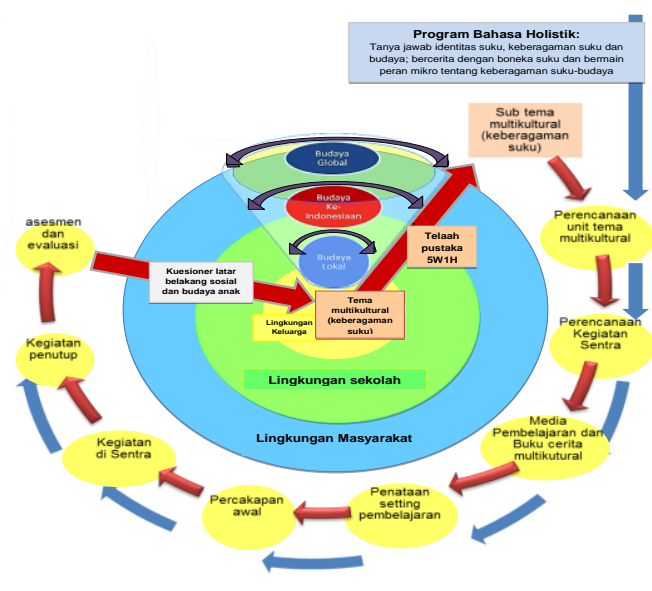

Gambar 9. Model Konseptual Pendidikan Multikultural melalui Program Bahasa
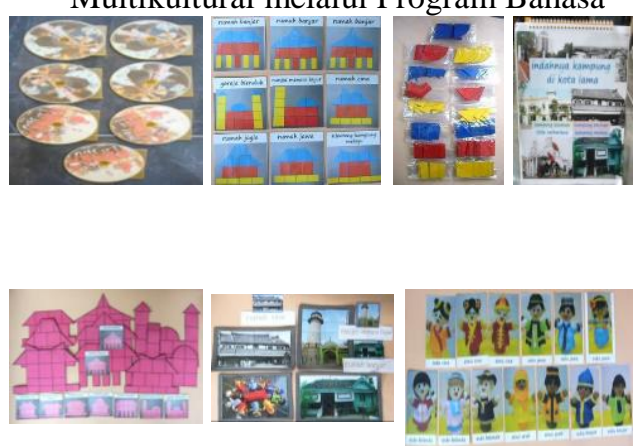

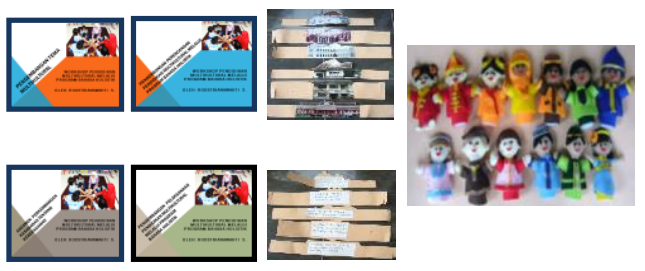

Gambar 10. Model Fisikal Pendidikan Multikultural melalui Program Bahasa Holistik prosedural model draft 1 menjadi model draft 2 dan model final:

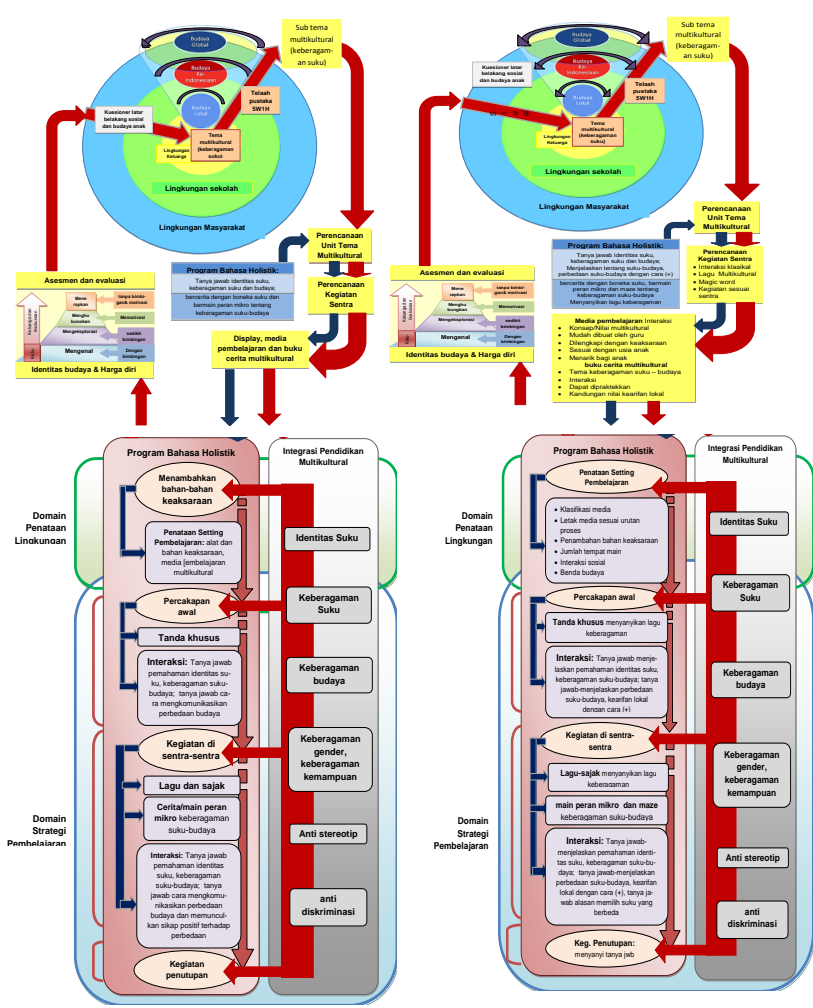

Gambar 11. Model Prosedural Pendidikan Multikultural melalui Program Bahasa Holistik

\section{Kelayakan Model melalui Expert Judgement}

Model dinyatakan layak oleh pakar pendidikan Multikultural yaitu HAR. Tilaar dan Theresia K. Ibrahim, pakar pengembangan model 
pembelajaran Syarif Sumantri, pakar bahasa holistik Sabarti Akhadiah dan pakar PAUD Sofia Hartati. Evaluasi pakar dilakukan melalui wawancara dan pengisian instrumen. Ada empat saran untuk pengembangan model yaitu: (1) identifikasi tema multikultural sesuai dengan latar belakang sosial dan budaya anak dan telaah pustaka tentang Budaya lokalKe-Indonesiaan-Global; (2) sampel penelitian kecil, dibatasi satu sekolah dan dari kelas yang paling beragam sukunya; (3) perencanaan pembelajaran menggunakan tema multikultural "keberagaman suku" untuk mengenal dan mengerti nilainilai sosial-budaya dari suku lain; (4) asesmen keberagaman difokuskan pada identitas bangsa dan harga diri yang kuat (inti Nasionalisme).

\section{PEMBAHASAN}

Temuan penelitian ini adalah perkembangan kesadaran tentang keberagaman akan tinggi karena pengaruh dua faktor utama yaitu (1) kemampuan berkomunikasi (bahasa lisan) dan, (2) pengalaman bersosialisasi di luar lingkungan keluarga (partisipasi). Faktor pendukung berupa media dengan tulisan dan buku cerita multikultural (bahasa tulisan), bimbingan dan motivasi dari guru dan teman sebaya (pijakan untuk berinteraksi dan berkomunikasi), boneka suku untuk media berkomunikasi (berinteraksi), media pembelajaran serupa tapi berbeda dan sama tapi beragam (berkomunikasi tentang keberagaman). Temuan ini sesuai dengan konsep "Aku dan Aku yang lain" (identitas diri dalam keberagaman) sebagai proses individuasi dan partisipasi (Tilaar, 2002: 276).

$$
\text { Interpretasi data tahapan }
$$
perkembangan kesadaran tentang keberagaman anak diperoleh dari pengamatan yang dicatat di catatan lapangan dan portofolio, rekapitulasi di review portofolio, lalu dikategorisasikan menjadi empat tahapan. Tahapan tersebut merupakan konstruk konsep tahapan perkembangan kesadaran tentang keberagaman AUD (Content Validity) yang berlaku untuk empat kelompok indikator asesmen yaitu (1) pemahaman identitas suku keluarganya (8 item); (2) pemaham- 
an keberagaman suku dan budaya di lingkungan TK dan masyarakat (5 item); (3) keterampilan berkomunikasi dalam kelompok suku dan budaya yang beragam (3 item); (4) perilaku positif terhadap keberagaman suku dan budaya (3 item). Dari 19 item indikator ada 15 yang muncul satu kali dan ada 4 yang berulang sehingga tahapan yang muncul pertama merupakan pre-test dan yang muncul terakhir merupakan post-test. Berikut adalah tabel uji signifikansi:

Tabel 2. Uji Signifikansi indikator asesmen pada Uji Coba Kelompok Kecil

\begin{tabular}{|c|c|c|c|l|}
\hline $\begin{array}{c}\text { Indikator } \\
\text { Penilaian }\end{array}$ & $\begin{array}{c}\text { Jumlah } \\
\text { Sampel } \\
\text { (n) }\end{array}$ & $\begin{array}{c}\text { Nilai } \\
\text { Statistik } \\
\text { Wilcoxon } \\
(\mathrm{T})\end{array}$ & $\begin{array}{c}\text { Nilai } \\
-\mathrm{p}\end{array}$ & Keputusan \\
\hline Nama suku & 6 & 6 & 0,091 & Signifikan \\
\hline Suku Mas & 6 & 15 & 0,030 & Signifikan \\
\hline Kulit & 5 & 6 & 0,091 & Signifikan \\
\hline Budaya & 6 & 10 & 0,050 & Signifikan \\
\hline
\end{tabular}

\section{KESIMPULAN}

Kesimpulan penelitian ini adalah: (1) model pendidikan multikultural umumnya dilakukan pada perayaan hari besar Nasional dan Agama; (2) tingkat kesadaran tentang keberagaman AUD pada awal adalah tahapan sedang dan kurang; (3) rancangan model Pendidikan Multikultural dikembangkan melalui konsep pengembangan tema multikultural, asesmen perkembangan kesadaran tentang keberagaman, perencanaan dan pelaksanaan pembelajaran model webbed, serta cerita multikultural; (4) strategi pelaksanaan model pendidikan multikultural melalui beberapa tahapan yaitu: studi pustaka tema multikultural, studi lapangan melalui kuesioner, revisi rancangan model s.d. model final melalui validasi pakar, hasil telaah pustaka, studi lapangan latar belakang sosialbudaya, evaluasi guru dan analisis data kualitatif; (5) Uji efektifitas model mempunyai pengaruh dan terjadi peningkatan tahapan perkembangan kesadaran tentang keberagaman.

\section{DAFTAR PUSTAKA}

Banks, J.A., and Banks, C.A. Multicultural Education: Issues and Perspectives. San Fransisco: Jossey-Bass Education. 2004.

Berk, E., Laura, Child development, seventh edition. Boston: Person education, 2006.

Borg, R. Walter, Meredith Gall, Joice P. Gall, Education 
Pendidikan Multikultural Melalui.....

Roostrianawahti Soekmono

Research An Introduction.

Eighth Edition, Boston: Allyn and Bacon, 2007.

Connell, Patricia, et.al. Early Years Curriculum Guidelines.

Brisbane: Queensland Studies Authority, 2006

Dewantara, Ki Hajar, Karya Ki Hajar Dewantara: Pendidikan, Cetakan Kedua, Yogyakarta: Majelis Luhur Persatuan Taman Siswa, 1977.

Digilib.uin, "Pendidikan Multikultural pada Anak Usia Dini"

http://digilib.uin-suka.ac.id/6823/ 1/BAB\%20I,IV.pdf (diakses pada tanggal 15 April 2014)

Dodge, T.D., Laura J.C., Cate H., The Creative Curriculum for preschool, fourt edition. Washington DC: Teaching Strategies Inc. ,2002.

Klefsald, Jill Kimberly C. Martinez, Promoting Young Children's Cultural Awareness and Appreciation Through Multicultural Books. Vol. 68 Issue 5, Wisconsin: Young Children NAEYC, 2013.

McNeill dan Brian W. An Exercise in Ethnic Identity Awareness. Vol. 29 Issue 4. Washington DC: Journal of Multicultural Counseling \& Development, 2001.

Piper, D., Language Growth in the Multiethnic Classroom Language Arts, 1986, dalam Liz Rothlein, Terri Christman Wild, Read It Again! Multicultural Book. Illionis: Good Year Books, 1999

Raines, C., Shirley, Robert J. Canady. The Whole Language Kindergarten. New York:
Teachers College Columbia University, 1990.

Suliyati, Titiek. "Dinamika Kawasan Permukiman Etnis di Semarang". http://eprints. undip.ac.id. Diakses tanggal 11 Pebruari 2014

Tilaar, H.A.R., Multikulturalisme: Tantangan-tantangan Global Masa Depan dalam Transformasi Pendidikan Nasional, Jakarta: Grasindo, 2004. , Perubahan Sosial dan Pendidikan: pengantar pedagogik Transformatif untuk Indonesia. Jakarta: Grasindo, 2002.

Unika Atmajaya, "Sosialisasi Awal Program Pendidikan Multikulturalisme untuk Anak Usia Sekolah" http://www.atmajaya. ac.id/sosialisasi-awal-programpendidikabn-multikulturalismeuntuk-anak-usia-sekolah (diakses pada tanggal 15 April 2014.

Weaver, Constance, Understanding Whole Language: from principles to practice. Ontario: Irwin Publishing, 1990.

Wibisono, Yusuf. Metode Statistik, Yogyakarta: Gadjah Mada University Press, 2009.

Williams, David, alih bahasa Lexy J. Moleong, Penelitian Naturalistik, Jakarta: Pascasarjana IKIP Jakarta, 1989.

Wright, Alejandro. The Child's Conception of Racial Classification. In M.M. Spencer, G.K. Brookins, \& W.R. Allen (Eds), Beginnings: The Social and Affective Development of Black Children, Hillsdale (New York: Erlbaum,), h.186, 1985. 